\title{
INVESTMENT OBJECTIVES AND FACTORS THAT INFLUENCE THE DISAPPEARANCE OF SPANISH MUTUAL FUNDS
}

\author{
M. Glòria BARBERÀ-MARINÉ(D), Laura FABREGAT-AIBAR (D)*, \\ Antonio TERCEÑO
}

Department of Business Management, Faculty of Business and Economics, Reus, Spain

Received 16 July 2018; accepted 04 December 2019

\begin{abstract}
This paper analyses which variables influence the disappearance of mutual funds in the Spanish market and whether these variables vary depending on the investment objectives. The following variables are tested: age, size, investment flows, return, volatility, Sharpe ratio, Morningstar rating, and fund family. The Kaplan-Meier estimator and an extension of the Cox model, the Andersen-Gill model are used and the results indicate that the impact of some variables on survival capacity is different depending on the fund's investment objectives. The originality of this article is twofold. The analysis of disappearance takes the investment objectives of the mutual funds into account and a new variable, the Morningstar rating, is introduced. Moreover, no previous study examines survival capacity in the Spanish market according to different investment objectives. In Spain, mutual funds are highly concentrated because most of them are in the hands of a small number of banks who also control the country's largest fund families. This characteristic not only makes the Spanish market an interesting one for analysis, but it also means that the results of this paper are significant for mutual fund investors.
\end{abstract}

Keywords: mutual funds, investment objectives, survival capacity, Cox model, Andersen-Gill model, Spanish market.

JEL Classification: G1, G2.

\section{Introduction}

In recent years, the total net assets of mutual funds in Spain has registered a considerable increase to become one of the main investment instruments. At the end of 2016, total net assets reached a total of 235,341 million euros, 53\% up on the previous three years.

The main purpose of this article is to determine which variables influence the disappearance of mutual funds in the Spanish market and whether these vary depending on the investment objectives. Some studies consider that mutual fund policy plays an important

${ }^{\star}$ Corresponding author. E-mail: laura.fabregat@urv.cat

This is an Open Access article distributed under the terms of the Creative Commons Attribution License (http://creativecommons. org/licenses/by/4.0/), which permits unrestricted use, distribution, and reproduction in any medium, provided the original author and source are credited. 
role in the survival of mutual funds (Jayaraman et al., 2002; Bu \& Lacey, 2008; Namvar \& Phillips, 2013; Filip, 2014). However, these studies only focus on equity funds, distinguishing between those that invest in stocks with strong growth prospects in terms of profits or sales (growth funds), those that invest in undervalued stocks with respect to their financial and accounting ratios (value funds), and those that combine the two aforementioned strategies (blend funds).

The National Securities Market Commission (CNMV) Circular 3/2011, of 9 June, classified mutual funds in the Spanish market into fifteen investment objectives depending on the type of assets the portfolio invested in. Eight of these investment objectives are studied in this research, grouped into two categories: i) bond funds and bond mixed funds; and ii) equity funds and equity mixed funds. The other categories are discarded because of the low number of funds available.

The Andersen-Gill model, an extension of the Cox model, is applied to both groups to analyze whether there is a relation between the risk of disappearance and the variables considered in this study. First, the Cox model is applied. A condition that must be satisfied to apply this model is that the risks are proportional. However, in this case, the risks are shown to not be proportional. Consequently, the Andersen-Gill model is used because it does not require the satisfaction of this condition. In the literature, the Cox model is used to estimate fund survival in various studies such as Lunde et al. (1999), Cameron and Hall (2003), Bu and Lacey (2008), and Linnainmaa (2013).

The following variables are used in this analysis: age, size, investment flows (calculated from the variation in size at 1 and 2 years), return (calculated from the returns at 1 and 3 years), volatility (calculated from the standard deviation at 1 and 3 years), risk-adjusted return (measured as Sharpe ratio), fund family, and the Morningstar rating.

The main contribution of this paper is the analysis based on investment objectives. Given the different investment profiles of the two categories, the impact of the variables on survival capacity may vary. Furthermore, most studies in this field have focused on equity funds, and very few of them consider the Spanish market (Fabregat-Aibar et al., 2017; Terceño et al., 2018).

The fund family and the Morningstar rating are also included as variables in the analysis. Regarding the fund family, Spanish mutual funds are mainly managed by banks as opposed to independent companies. At the end of 2016, the six main fund families, which are linked to the banks Caixabank, Santander, BBVA, Banco Sabadell, Bankia, and Kutxabank, managed a total of 149,002 million euros, $63.3 \%$ of the total net assets. There is, therefore, a considerable level of concentration in the Spanish market with most mutual funds in the hands of a small number of banks who also control the country's largest fund families. This predominance in the market makes it easier for these fund families to close and merge mutual funds because they have a wider range of funds with similar investment objectives than smaller fund families, which have a more limited offer. It would be expected, therefore, that mutual funds managed by banks are more at risk of disappearing than those whose fund family is either independent or an insurance company.

And last, the inclusion of a variable linked to risk and complementary to volatility is proposed: the Morningstar rating. 
The paper is structured in six sections. The literature on the factors that influence the disappearance of mutual funds is reviewed and the hypotheses are presented in Section 1. The methodology used - the Kaplan-Meier estimator, the Cox model, and the Andersen-Gill model - is presented in Section 2. The data and their sources are examined in Section 3. The analysis and application of the results are presented in Section 4. And last, the results are discussed and the conclusions drawn in Sections 5 and 6.

\section{Literature review}

There is empirical evidence to suggest that the age of the fund influences its survival capacity. Some studies conclude that younger funds have a higher probability of disappearing (Ter Horst et al., 2001; Zhao, 2005; Khorana et al., 2007; Bu \& Lacey, 2008; Rohleder et al., 2011; Boubakri et al., 2014; Lapatto \& Puttonen, 2018). Unlike previous results, Lunde et al. (1999) observes that both the youngest and the oldest funds are less likely to disappear. More than $70 \%$ of funds in their sample disappeared within 3 to 15 years from their creation. Furthermore, $2 \%$ of their sample ( 21 out of 973 funds) disappeared in the first six months. Likewise, Cameron and Hall (2003) observes that 25\% of their sample of Australian funds disappeared within the first six years and 50\% had disappeared twelve years after their creation. This line of argument is hypothesized as:

H1: Age decreases the risk of a fund disappearing

Other studies such as Zhao (2005), Rohleder et al. (2011), and Sherrill and Stark (2018) consider that fund size plays an important role in its disappearance since smaller funds have a higher probability of disappearing. Moreover, Zhao (2005) adds that the disappearance of a fund occurs in smaller portfolios that have a smaller variety of assets. Based on this argument, the following hypothesis is formulated:

\section{H2: Larger size decreases the risk of a fund disappearing}

Closely related to fund size, there is empirical evidence to suggest that investment inflowsoutflows can influence the disappearance or survival of funds. Ding (2006) analyzes a sample of 604 equity funds from the US market during the period 1962-1999, finding that older funds show outflows during the three years prior to closing, while younger funds present fund inflows up to the final year, which is when investors begin to withdraw capital due to the drop in performance intensely. Ding (2006), Allen and Parwada (2006), Boubakri et al. (2014) and Andreu and Sarto (2016) consider that there is an intense withdrawal of capital from mutual funds in response to uncertain, unstable economic situations. So, the following statement is hypothesized:

\section{H3: A positive change in net flow decreases the risk of a fund disappearing}

Several studies show that a poor past performance increases the probability of disappearance and intensifies investment outflows (Brown \& Goetzmann, 1995; Carhart, 1997; Lunde et al., 1999; Jayaraman et al., 2002; Asebedo \& Grable, 2004; Zhao, 2005; Bu \& Lacey, 2008; Rohleder et al., 2011; Linnainmaa, 2013; Filip, 2014; Cogneau \& Hübner, 2015; Andreu \& 
Sarto, 2016). Cogneau and Hübner (2015) analyze a sample of equity funds during the period 1994-2010, distinguishing them by currency (GBP, EUR, USD, JPY and CHF) and domicile (United Kingdom, Luxembourg, France, Italy, Belgium, and Austria), considering that the disappearance of mutual funds can be predicted from their performance in the previous year. However, two of the earliest studies on the survival capacity of mutual funds consider that a poor performance for three consecutive years increases the probability of disappearance (Brown \& Goetzmann, 1995) and that a fund does not survive if it performs poorly for five consecutive years (Carhart, 1997). So, the hypothesis is:

H4: A higher return decreases the risk of a fund disappearing

Other studies such as Elton and Gruber (1996), Cameron and Hall (2003), Massa and Patgiri (2009), and McLemore (2019) analyze the risk of the fund calculated from its volatility. These studies conclude that the more volatile a fund, the greater the likelihood it will disappear. However, Asebedo and Grable (2004) affirms that risk cannot be a key factor in the survival of funds because higher risk does not imply better or worse performance. Therefore, the hypothesis is:

\section{H5: A greater volatility increases the risk of a fund disappearing}

Some studies such as Lapatto and Puttonen (2018) confirms that target portfolios have lower Sharpe ratios in the pre-merger period than their acquiring funds for different time periods and merger types. So the following hypothesis is formulated:

\section{H6: A higher Sharpe ratio decreases the risk of a fund disappearing}

Some studies use the Morningstar rating as a risk measure (Blake \& Morey, 2000; Del Guercio \& Tkac, 2010). They conclude that a low rating ( 1 or 2 stars) indicates poor performance, while there is no evidence to show that the best-rated funds ( 5 stars) perform better than those rated with 3 or 4 stars. Regarding the survival approach, Oehler et al. (2018) recently concluded that the funds with a low rating have a higher risk of fund closure. Based on this line of argument, the following hypothesis is formulated:

\section{H7: A higher Morningstar rating decreases the risk of a fund disappearing}

Khorana et al. (2007) and Park (2013) analyze the incidence of the fund family on the survival capacity of mutual funds. Khorana et al. (2007) examine a sample of US equity funds during the period 1999-2001, concluding that closure is more likely when the fund family is independent. This study considers that if the board is independent, it tends to be less tolerant of negative results and decides to act quickly for the benefit of the fund and its investors. On the other hand, Park (2013), in which a US equity sample for the period 1991-2004 was studies, states that funds with the same marketing company have a higher probability of disappearing because their closure allows a greater scale economies to be generated, which consequently reduce costs for the entities. Given these studies and the specific structure of the Spanish market, the following statement is hypothesized:

H8: Mutual funds managed by banks are at greater risk of disappearing than when the fund is managed by an insurance company or an independent company 


\section{Methodology}

Survival models are based on a set of concepts, instruments, and techniques designed to study the time that elapses until a specific event of interest occurs (Fuentelsaz et al., 2004; Kleinbaun \& Klein, 2012).

In this study, the empirical analysis is carried out in two stages. First, the survival probability of the funds is analyzed in two large groups: (1) bond funds and bond mixed funds ${ }^{1}$ and (2) equity funds and equity mixed funds ${ }^{2}$. The influence of the fund family on the survival capacity of the two groups is also assessed using the non-parametric Kaplan-Meier estimator (1958). Second, a multivariant analysis is carried out to assess the effect each explicative variable has on the survival of funds. The Cox model (1972) is used if the assumption of proportional hazard is met, and the Andersen-Gill model (1982) is applied if this premise cannot be verified.

\subsection{Kaplan-Meier estimator (1958)}

The Kaplan-Meier estimator is one of the most used models in this type of research. It enables the survival function to be obtained taking censured data into account and comparing two or more survival curves to determine whether they are significantly different.

This instrument estimates the survival probability, $\mathrm{S}(\mathrm{t})$, at the different moments the event occurs.

To do so, survival times ordered from smallest to largest must be known:

$$
t_{o}<t_{1}<t_{2}<\ldots<t_{n}
$$

where the origin is $t_{o}$ and the first event is produced in $t_{1}$. For each $t_{i}, d_{i}$ denotes the number of events produced at this moment, and $n_{i}$ is the number of individuals at risk just before $t_{i}$.

The Kaplan-Meier estimator defines survival function as:

$$
\hat{S}(t)=\prod_{t_{i}<t} \frac{n_{i}-d_{i}}{n_{i}} .
$$

The most used test to compare survival curves is the non-parametric Log-Rank test.

\subsection{Cox (1972) and Andersen-Gill (1982) models}

The Cox proportional hazard model, unlike the estimator discussed above, analyses whether there is a relationship between the risk of a certain event occurring and one or several explicative variables.

\footnotetext{
${ }^{1}$ According to the definition provided by the CNMV, the percentage invested in Treasury bills and bonds is $100 \%$, and for bond mixed funds the percentage invested in Treasury bills and bonds is more than 70\%. Therefore, the percentage invested in stocks is less than $30 \%$.

2 According to the CNMV definition, for equity funds the percentage invested in stocks is more than $75 \%$, and for equity mixed funds the percentage invested in stocks is between $30-75 \%$.
} 
This model provides an expression for measuring the risk for an individual $j$ at a moment $t$ given a set of explicative variables denoted as $X=\left(X_{1}, X_{2}, \ldots, X_{p}\right)$ and formulated in the following way:

$$
h_{j}(t, X)=h_{o}(t) e^{\sum_{i=1}^{p} \beta_{i} X_{i}}
$$

where $h_{o}(t)$ is the baseline hazard, in other words the risk of the event occurring simply due to the passing of time when all the variables take the value 0 . The factor $e^{\sum_{i=1}^{p} \beta_{i} X_{i}}$ is the parametric part of the model and only depends on the explicative variables, with $\beta_{i}$ being the estimated parameters for the model. The Cox model, therefore, is considered as 'semiparametric', given that it has both a parametric and a non-parametric part.

To consider the parameters $\beta_{i}$ as valid, the main assumption of the model, the proportional hazard, must be satisfied. This hypothesis requires that the risk for an individual is proportional to the risk for any other individual, irrespective of time.

The Schoenfeld residuals (1982) are used to verify the assumption of proportional hazard.

Andersen-Gill extends the Cox model for recurring events and for explicative variables dependent on time. Furthermore, it is used for cases where the assumption of proportional hazard is not met, even if the event is non-recurring.

The expression to measure the risk of an individual $j$ at a moment $t$ is formulated as follows:

$$
h_{j}(t, X)=Y_{j}(t) \cdot h_{o}(t) e^{\sum_{i=1}^{p} \beta_{i} X_{i}(t)},
$$

where $e^{\sum_{i=1}^{p} \beta_{i} X_{i}(t)}$ is the parametric part of the model, $h_{o}(t)$ is the baseline hazard, and $Y_{j}(t)$ indicates if the $j^{\text {th }}$ individual is still in observation in $t$.

\section{Data}

The databases are provided by the Spanish National Securities Market Commission (CNMV) and Morningstar Direct. The first provides information about the funds that disappeared during the study period, and the values of the variables used are obtained from the second.

A sample of 1,057 mutual funds is used, which corresponds to all the funds alive at the end of 2003, plus all the funds registered from then until 2016 for which all the required variables are available. Of this total number of funds, 604 (equivalent to $57 \%$ of the sample) had disappeared.

The sample is divided into two groups: The first is the bond funds group, which contains a total of 553 bond funds and bond mixed funds (358 of which had disappeared), and the second group is comprised of 504 equity funds and equity mixed funds ( 246 of which had also disappeared) (Table 1).

It must be pointed out that the sample includes both right-censored data, because some of the funds were alive at the end of 2016 (Kleinbaun \& Klein, 2012), and left-truncated data 
(commonly known as late entry data), given that some funds were registered after 2003 and were also incorporated into the analysis (Klein \& Moeschberger, 2003).

Table 2 lists the variables used in the analysis along with their definition, and Table 3 details the main statistics for each variable for the two groups. The fund expenses are excluded due to a lack of information in the database after 2014.

Table 1. Number of disappeared funds per year

\begin{tabular}{|c|c|c|}
\hline & Bond funds & Equity funds \\
\hline 2006 & 6 & 3 \\
\hline 2007 & 3 & 4 \\
\hline 2008 & 10 & 8 \\
\hline 2009 & 59 & 36 \\
\hline 2010 & 36 & 20 \\
\hline 2011 & 33 & 26 \\
\hline 2012 & 78 & 53 \\
\hline 2013 & 67 & 51 \\
\hline 2014 & 24 & 25 \\
\hline 2015 & 25 & 12 \\
\hline 2016 & 17 & 8 \\
\hline Total & 358 & 246 \\
\hline
\end{tabular}

Table 2. Study variables in the survival model

\begin{tabular}{|l|l|l|}
\hline \multicolumn{2}{|c|}{ Variable } & \multicolumn{1}{c|}{ Description } \\
\hline Age & $\begin{array}{l}\text { Number of years elapsed between creating the fund and its } \\
\text { disappearance or, where the event has not occurred, until 2016. }\end{array}$ \\
\hline Size & $\begin{array}{l}\text { Logarithm of the total net assets (TNA) of the fund, in euros, on } \\
31 / 12 / 2016 \text { or 31/12 of the year before its disappearance. }\end{array}$ \\
\hline \multirow{2}{*}{$\begin{array}{l}\text { Investment } \\
\text { flows }\end{array}$} & $\begin{array}{l}\text { Variation in size } \\
\text { at 1 year }\end{array}$ & $\begin{array}{l}\text { Variation in TNA, expressed as a percentage in the year prior to its } \\
\text { disappearance or the change between 31/12/15 and 31/12/16 if the } \\
\text { fund is still alive. }\end{array}$ \\
\cline { 2 - 3 } & $\begin{array}{l}\text { Variation in size } \\
\text { at 2 years }\end{array}$ & $\begin{array}{l}\text { Variation in TNA, expressed as a percentage two years prior to its } \\
\text { disappearance or the variation between 31/12/14 and 31/12/16 if } \\
\text { the fund is still alive. }\end{array}$ \\
\hline \multirow{2}{*}{ Return } & Annual return & $\begin{array}{l}\text { Annual return of the fund in the year prior to its disappearance or } \\
\text { in 2016 if the fund is still alive. }\end{array}$ \\
\cline { 2 - 3 } & $\begin{array}{l}\text { Annualised } \\
\text { return at 3 years }\end{array}$ & $\begin{array}{l}\text { Annualized return for the three years prior to its disappearance or } \\
\text { between 2014 and 2016 if the fund is still alive. }\end{array}$ \\
\hline Volatility & $\begin{array}{l}\text { Annual standard } \\
\text { deviation }\end{array}$ & $\begin{array}{l}\text { Calculated from the monthly returns in 2016 or in the year prior to } \\
\text { its disappearance. }\end{array}$ \\
\hline
\end{tabular}

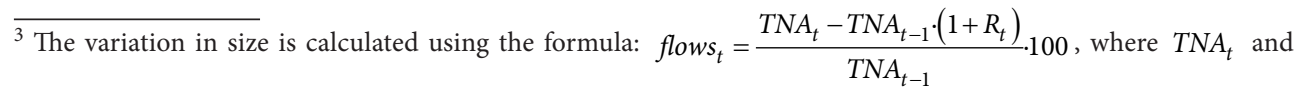
$T N A_{t-1}$ are the total net assets in year $t$ and $t-1$, and $R_{t}$ is the fund return in year $t$. 
End of Table 2

\begin{tabular}{|l|l|}
\hline \multicolumn{1}{|c|}{ Variable } & \multicolumn{1}{c|}{ Description } \\
\hline $\begin{array}{l}\text { Standard } \\
\text { deviation } \\
\text { annualised at } 3 \\
\text { years }\end{array}$ & $\begin{array}{l}\text { Calculated from the monthly returns using the same criteria as for } \\
\text { the annualised return at 3 years. }\end{array}$ \\
\hline Sharpe ratio &
\end{tabular}

Table 3. Descriptive analysis of the study variables

\begin{tabular}{|c|c|c|c|c|}
\hline & Minimum & Maximum & Mean & Standard Deviation \\
\hline \multicolumn{5}{|c|}{ A) Bond funds } \\
\hline Age & 4.000 & 29.000 & 14.966 & 6.184 \\
\hline Size & 12.407 & 22.092 & 16.933 & 1.730 \\
\hline Variation in size_1 yr & -94.747 & 52.322 & -20.675 & 27.348 \\
\hline Variation in size_2 yrs & -97.578 & 101.449 & -28.489 & 39.373 \\
\hline Return_1 yr & -21.875 & 22.504 & 0.747 & 3.921 \\
\hline Return_3 yrs & -7.425 & 16.804 & 1.199 & 2.093 \\
\hline Deviation_1 yr & 0.017 & 17.378 & 2.622 & 2.356 \\
\hline Deviation_3 yrs & 0.044 & 13.168 & 2.754 & 2.202 \\
\hline Sharpe ratio & -19.556 & 4.596 & -1.359 & 2.925 \\
\hline \multicolumn{5}{|c|}{ B) Equity funds } \\
\hline Age & 4.000 & 29.00 & 14.071 & 5.714 \\
\hline Size & 11.627 & 21.905 & 16.522 & 1.481 \\
\hline Variation in size_1 yr & -107.915 & 55.072 & -12.821 & 22.520 \\
\hline Variation in size_2 yrs & -126.974 & 104.823 & -9.747 & 42.259 \\
\hline Return_1 yr & -37.748 & 34.157 & 0.635 & 12.086 \\
\hline Return_3 yrs & -16.392 & 17.604 & 1.635 & 6.189 \\
\hline Deviation_1 yr & 1.014 & 29.960 & 12.765 & 5.470 \\
\hline Deviation_3 yrs & 2.148 & 28.797 & 13.081 & 5.000 \\
\hline Sharpe ratio & -2.871 & 2.311 & 0.003 & 0.952 \\
\hline
\end{tabular}

Table 4 shows the distribution of the sample according to the stars provided by Morningstar.

${ }^{4}$ The Sharpe ratio is calculated using the formula: $S R=\frac{R_{t}-R_{f r}}{\delta_{t}}$, where $R_{t}$ is the fund return in year $t, R_{f r}$ is the risk free rate in year $t$ ( $3 y$ Bond Spain), and $\delta_{t}$ is the volatility of the fund in year $t$. 
Table 4. Descriptive analysis of the Morningstar Rating for the two groups

\begin{tabular}{|c|c|c|c|c|c|c|c|c|}
\hline & \multicolumn{4}{|c|}{ Disappeared funds } & \multicolumn{4}{|c|}{ Surviving funds } \\
\hline \multicolumn{9}{|c|}{ A) Bond funds } \\
\hline & $\begin{array}{l}\text { Number } \\
\text { of funds }\end{array}$ & $\begin{array}{l}\% \text { of } \\
\text { funds }\end{array}$ & $\begin{array}{l}\text { Mean of } \\
\text { age }\end{array}$ & $\begin{array}{l}\text { Mean of } \\
\text { size }\end{array}$ & $\begin{array}{l}\text { Number } \\
\text { of funds }\end{array}$ & $\begin{array}{l}\% \text { of } \\
\text { funds }\end{array}$ & $\begin{array}{l}\text { Mean of } \\
\text { age }\end{array}$ & $\begin{array}{c}\text { Mean of } \\
\text { size }\end{array}$ \\
\hline 1 star & 56 & 15.6 & 14 & 15.375 & 8 & 4.1 & 20 & 17.296 \\
\hline 2 stars & 125 & 34.9 & 15 & 16.372 & 61 & 31.3 & 17 & 17.530 \\
\hline 3 stars & 115 & 32.1 & 14 & 16.708 & 70 & 35.9 & 15 & 17.931 \\
\hline 4 stars & 54 & 15.1 & 12 & 16.980 & 40 & 20.5 & 17 & 18.152 \\
\hline 5 stars & 8 & 2.2 & 11 & 17.436 & 16 & 8.2 & 14 & 18.092 \\
\hline Total & 358 & & & & 195 & & & \\
\hline \multicolumn{9}{|c|}{ B) Equity funds } \\
\hline & $\begin{array}{l}\text { Number } \\
\text { of funds }\end{array}$ & $\begin{array}{l}\% \text { of } \\
\text { funds }\end{array}$ & $\begin{array}{c}\text { Mean of } \\
\text { age }\end{array}$ & $\begin{array}{l}\text { Mean of } \\
\text { size }\end{array}$ & $\begin{array}{l}\text { Number } \\
\text { of funds }\end{array}$ & $\begin{array}{l}\% \text { of } \\
\text { funds }\end{array}$ & $\begin{array}{c}\text { Mean of } \\
\text { age }\end{array}$ & $\begin{array}{c}\text { Mean of } \\
\text { size }\end{array}$ \\
\hline 1 star & 41 & 16.7 & 13 & 15.509 & 44 & 17.1 & 16 & 17.015 \\
\hline 2 stars & 67 & 27.2 & 13 & 15.730 & 75 & 29.1 & 16 & 16.969 \\
\hline 3 stars & 87 & 35.4 & 14 & 15.761 & 107 & 41.5 & 15 & 17.570 \\
\hline 4 stars & 44 & 17.9 & 11 & 15.341 & 26 & 10.1 & 14 & 17.959 \\
\hline 5 stars & 7 & 2.8 & 10 & 15.327 & 6 & 2.3 & 16 & 19.224 \\
\hline Total & 246 & & & & 258 & & & \\
\hline
\end{tabular}

\section{Results}

\subsection{Kaplan-Meier estimator (1958)}

a) Bond funds

Figure 1 shows the survival function for the set of bond funds. The broken lines are the confidence intervals of 95\% (95\% CI) around the estimated curve. Regarding the likelihood of survival, $75 \%$ of the funds survive for 12 years, $50 \%$ for 17 years, and $25 \%$ for 22 years.

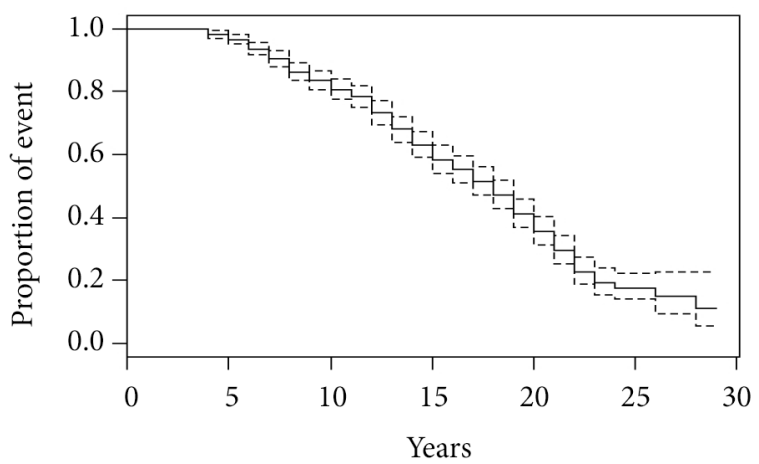

Figure 1. Survival curve - Bond funds 
Figure 2 shows the survival curves for the set of bond funds for the different types of fund families and Table 5 details their survival capacity. The results clearly show that funds belonging to insurance companies survive longer than those belonging to banks or independent companies, whose survival capacities are very similar.

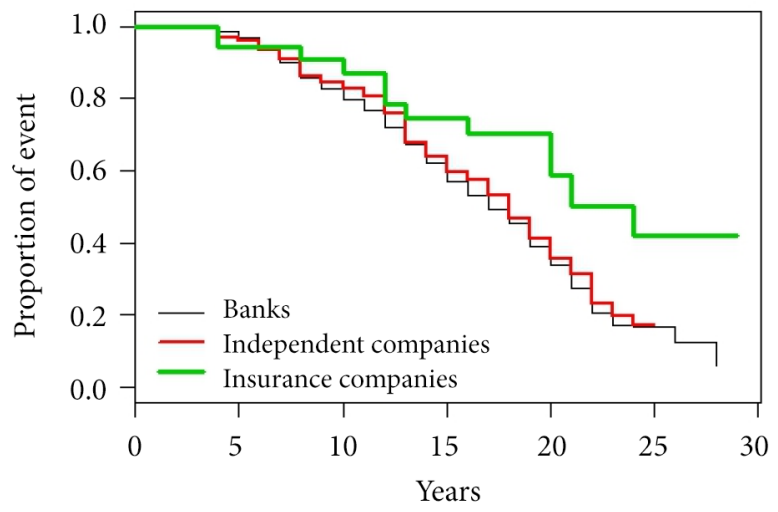

Figure 2. Survival curves according to the fund family - Bond funds

The results show that funds belonging to banks or independent companies have a $25 \%$ probability of disappearing at 12 years, while this probability is not reached for funds belonging to insurance companies until 13 years.

The probability of disappearing reaches $50 \%$ after 16 or 17 years for funds belonging to banks and 18 years for independent companies, whereas if the fund family is an insurance company this probability is not reached until 21 years.

Table 5. Kaplan-Meier estimator according to the fund family - Bond funds

\begin{tabular}{|c|c|c|c|c|c|c|c|c|c|}
\hline \multirow{2}{*}{ Age } & \multicolumn{4}{|c|}{ Banks } & \multicolumn{2}{c|}{ Independent companies } & \multicolumn{3}{c|}{ Insurance companies } \\
\cline { 2 - 11 } & n. risk & n. event & Survival & n. risk & n. event & Survival & n. risk & n. event & Survival \\
\hline 4 & 397 & 5 & 0.988 & 121 & 4 & 0.967 & 35 & 2 & 0.943 \\
\hline 5 & 387 & 7 & 0.970 & 115 & 1 & 0.959 & - & - & - \\
\hline 6 & 376 & 13 & 0.936 & 111 & 3 & 0.933 & - & - & - \\
\hline 7 & 355 & 14 & 0.899 & 108 & 3 & 0.907 & - & - & - \\
\hline 8 & 336 & 15 & 0.859 & 103 & 5 & 0.863 & 26 & 1 & 0.907 \\
\hline 9 & 317 & 12 & 0.827 & 97 & 2 & 0.845 & - & - & - \\
\hline 10 & 302 & 11 & 0.796 & 92 & 2 & 0.827 & 24 & 1 & 0.869 \\
\hline 11 & 291 & 10 & 0.769 & 86 & 2 & 0.807 & - & - & - \\
\hline 12 & 277 & 17 & 0.722 & 82 & 5 & 0.758 & 21 & 2 & 0.786 \\
\hline 13 & 260 & 17 & 0.675 & 76 & 8 & 0.678 & 19 & 1 & 0.745 \\
\hline 14 & 236 & 19 & 0.620 & 66 & 4 & 0.637 & - & - & - \\
\hline 15 & 215 & 18 & 0.568 & 61 & 4 & 0.595 & - & - & - \\
\hline 16 & 195 & 12 & 0.533 & 57 & 2 & 0.575 & 18 & 1 & 0.703 \\
\hline 17 & 175 & 13 & 0.494 & 54 & 4 & 0.532 & - & - & - \\
\hline
\end{tabular}


End of Table 5

\begin{tabular}{|c|c|c|c|c|c|c|c|c|c|}
\hline \multirow{2}{*}{ Age } & \multicolumn{4}{|c|}{ Banks } & \multicolumn{3}{c|}{ Independent companies } & \multicolumn{3}{c|}{ Insurance companies } \\
\cline { 2 - 11 } & n. risk & n. event & Survival & n. risk & n. event & Survival & n. risk & n. event & Survival \\
\hline 18 & 153 & 12 & 0.455 & 49 & 6 & 0.467 & - & - & - \\
\hline 19 & 131 & 18 & 0.393 & 43 & 5 & 0.413 & - & - & - \\
\hline 20 & 102 & 14 & 0.339 & 37 & 5 & 0.357 & 12 & 2 & 0.586 \\
\hline 21 & 76 & 14 & 0.276 & 32 & 4 & 0.312 & 7 & 1 & 0.502 \\
\hline 22 & 59 & 15 & 0.206 & 28 & 7 & 0.234 & - & - & - \\
\hline 23 & 37 & 6 & 0.173 & 20 & 3 & 0.199 & - & - & - \\
\hline 24 & 29 & 1 & 0.167 & 14 & 2 & 0.171 & 6 & 1 & 0.419 \\
\hline 26 & 4 & 1 & 0.125 & - & - & - & - & - & - \\
\hline 28 & 2 & 1 & 0.063 & - & - & - & - & - & - \\
\hline
\end{tabular}

The results of the Log-Rank contrast shown in Table 6 confirm that there are significant differences between survival functions according to the fund family.

Table 6. Log-Rank contrast to compare survival curves according to the fund family - Bond funds

\begin{tabular}{|l|c|c|c|c|c|}
\hline & $\mathrm{N}$ & Observed & Expected & $(\mathrm{O}-\mathrm{E})^{\wedge} 2 / \mathrm{E}$ & $(\mathrm{O}-\mathrm{E})^{\wedge} 2 / \mathrm{V}$ \\
\hline Fund family $=1$ & 397 & 265 & 252.4 & 0.627 & 2.328 \\
\hline Fund family $=2$ & 121 & 81 & 82.0 & 0.013 & 0.018 \\
\hline Fund family =3 & 35 & 12 & 23.6 & 5.671 & 6.692 \\
\hline
\end{tabular}

${ }^{*}$ Chisq $=6.9$ on 2 degrees of freedom, $\mathrm{p}=0.031$.

b) Equity funds

Figure 3 shows the survival function of the set of equity funds. The broken lines are the confidence intervals of $95 \%$ around the estimated curve. Regarding survival capacity, $75 \%$ of the funds survive for 13 years, 50\% for 18 years, and 25\% for more than 24 years. These results show (comparing them with Figure 1) that equity funds generally survive better than bond funds.

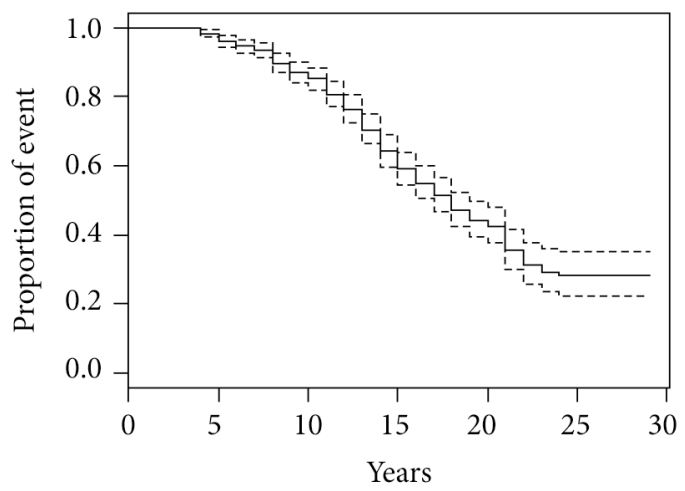

Figure 3. Survival curve - Equity funds 
Figure 4 shows the survival curves of the equity funds according to the different types of fund families and Table 7 details their survival capacity. Unlike the results obtained in the last section, the funds in this group with the greatest longevity are those managed by independent companies. There is a percentage of $26 \%(54 \%)$ of the funds managed by this type of fund family that disappear after 14 (21) years, while at the opposite extreme the funds managed by banks have a $39 \%(69 \%)$ probability of disappearing after 14 (21) years.

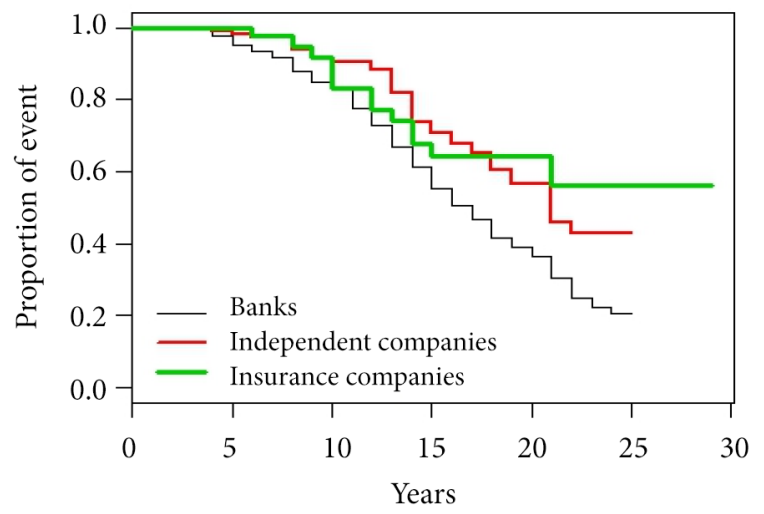

Figure 4. Survival curves according to the fund family - Equity funds

Table 7. Kaplan-Meier estimator according to the fund family - Equity funds

\begin{tabular}{|c|c|c|c|c|c|c|c|c|c|}
\hline \multirow{2}{*}{ Age } & \multicolumn{4}{|c|}{ Banks } & \multicolumn{2}{c|}{ Independent companies } & \multicolumn{3}{c|}{ Insurance companies } \\
\cline { 2 - 11 } & n. risk & n. event & Survival & n. risk & n. event & Survival & n. risk & n. event & Survival \\
\hline 4 & 356 & 8 & 0.978 & 105 & 1 & 0.990 & - & - & - \\
\hline 5 & 345 & 10 & 0.949 & 102 & 1 & 0.981 & - & - & - \\
\hline 6 & 314 & 5 & 0.934 & 96 & 1 & 0.971 & 42 & 1 & 0.976 \\
\hline 7 & 300 & 5 & 0.919 & - & - & - & - & - & - \\
\hline 8 & 294 & 13 & 0.878 & 91 & 3 & 0.939 & 34 & 1 & 0.947 \\
\hline 9 & 279 & 9 & 0.850 & 88 & 2 & 0.917 & 33 & 1 & 0.919 \\
\hline 10 & 266 & 4 & 0.837 & 79 & 1 & 0.906 & 32 & 3 & 0.833 \\
\hline 11 & 260 & 19 & 0.776 & - & - & - & - & - & - \\
\hline 12 & 236 & 14 & 0.730 & 73 & 2 & 0.881 & 27 & 2 & 0.771 \\
\hline 13 & 216 & 18 & 0.669 & 69 & 5 & 0.817 & 25 & 1 & 0.740 \\
\hline 14 & 198 & 17 & 0.611 & 60 & 6 & 0.735 & 23 & 2 & 0.676 \\
\hline 15 & 180 & 17 & 0.554 & 52 & 2 & 0.707 & 21 & 1 & 0.644 \\
\hline 16 & 153 & 13 & 0.507 & 50 & 2 & 0.679 & - & - & - \\
\hline 17 & 125 & 10 & 0.466 & 47 & 2 & 0.650 & - & - & - \\
\hline 18 & 105 & 11 & 0.417 & 41 & 3 & 0.602 & - & - & - \\
\hline 19 & 78 & 5 & 0.391 & 32 & 2 & 0.565 & - & - & - \\
\hline 20 & 46 & 3 & 0.365 & - & - & - & - & - & - \\
\hline
\end{tabular}


End of Table 7

\begin{tabular}{|c|c|c|c|c|c|c|c|c|c|}
\hline \multirow{2}{*}{ Age } & \multicolumn{4}{|c|}{ Banks } & \multicolumn{3}{c|}{ Independent companies } & \multicolumn{3}{c|}{ Insurance companies } \\
\cline { 2 - 11 } & n. risk & n. event & Survival & n. risk & n. event & Survival & n. risk & n. event & Survival \\
\hline 21 & 37 & 6 & 0.306 & 21 & 4 & 0.457 & 8 & 1 & 0.563 \\
\hline 22 & 27 & 5 & 0.249 & 17 & 1 & 0.430 & - & - & - \\
\hline 23 & 18 & 2 & 0.222 & - & - & - & - & - & - \\
\hline 24 & 15 & 1 & 0.207 & - & - & - & - & - & - \\
\hline
\end{tabular}

The Log-Rank contrast test (Table 8) confirms that there are significant differences between survival functions according to the fund family to which the mutual funds belong.

Table 8. Log-rank contrast to compare survival curves - Equity funds

\begin{tabular}{|l|c|c|c|c|c|}
\hline & $\mathrm{N}$ & Observed & Expected & $(\mathrm{O}-\mathrm{E})^{\wedge} 2 / \mathrm{E}$ & $(\mathrm{O}-\mathrm{E})^{\wedge} 2 / \mathrm{V}$ \\
\hline Fund family $=1$ & 356 & 195 & 168.3 & 4.25 & 14.43 \\
\hline Fund family $=2$ & 105 & 38 & 56.7 & 6.16 & 8.58 \\
\hline Fund family $=3$ & 43 & 13 & 21.0 & 3.08 & 3.59 \\
\hline
\end{tabular}

${ }^{*}$ Chisq $=14.5$ on 2 degrees of freedom, $\mathrm{p}=0.00072$.

\subsection{Andersen-Gill model}

a) Bond funds

First, the Cox model is applied and subsequently discarded as it does not meet the proportional hazard assumption. Consequently, the Andersen-Gill model is applied, which does not require this assumption to be fulfilled. Table 9 shows the parameters of the Andersen-Gill model for the bond funds group. The second column indicates the value of the estimated regression coefficient. The third column is the hazard ratio, which indicates the variation in the hazard function for a unitary increase in the associated variable. The fourth column is the standard error of the estimated regression coefficient, and the last two columns contain the statistic value and the p-value.

Table 9. Parameters of the Andersen-Gill model (11 variables) - Bond funds

\begin{tabular}{|l|c|c|c|c|c|}
\hline \multicolumn{1}{|c|}{ Variable } & coef & $\exp ($ coef $)$ & se(coef) & $\mathrm{z}$ & $\operatorname{Pr}(>|\mathrm{z}|)$ \\
\hline Age & -0.041 & 0.960 & 0.009 & -4.682 & $2.85 \cdot 10^{-6 * * *}$ \\
\hline Fund family = 2 & -0.264 & 0.768 & 0.137 & -1.922 & $0.054658 \cdot$ \\
\hline Fund family =3 & -0.845 & 0.429 & 0.300 & -2.823 & $0.004754^{* *}$ \\
\hline Size & -0.171 & 0.843 & 0.041 & -4.128 & $3.66 \cdot 10^{-5 * * *}$ \\
\hline Variation in size_1 yr & -0.003 & 0.998 & 0.003 & -0.912 & 0.361959 \\
\hline Variation in size_2 yrs & -0.006 & 0.994 & 0.002 & -2.848 & $0.004402^{\star *}$ \\
\hline Return_1 yr & -0.027 & 0.973 & 0.017 & -1.565 & 0.117579 \\
\hline Return_3 yrs & -0.054 & 0.947 & 0.040 & -1.375 & 0.169203 \\
\hline
\end{tabular}


End of Table 9

\begin{tabular}{|l|c|c|c|c|c|}
\hline \multicolumn{1}{|c|}{ Variable } & coef & $\exp ($ coef $)$ & se(coef) & $\mathrm{z}$ & $\operatorname{Pr}(>|\mathrm{z}|)$ \\
\hline Deviation_1 yr & 0.232 & 1.261 & 0.050 & 4.671 & $2.99 \cdot 10^{-6 * * *}$ \\
\hline Deviation_3 yrs & -0.192 & 0.825 & 0.057 & -3.345 & $0.00822^{* * *}$ \\
\hline Sharpe ratio & -0.012 & 0.988 & 0.007 & 1.673 & $0.094306 \cdot$ \\
\hline Rating = 2 & -0.269 & 0.764 & 0.187 & -1.437 & 0.150694 \\
\hline Rating = 3 & -0.265 & 0.767 & 0.199 & -1.334 & 0.182307 \\
\hline Rating = 4 & -0.471 & 0.624 & 0.232 & -2.032 & $0.042142^{\star}$ \\
\hline Rating = 5 & -1.115 & 0.328 & 0.418 & -2.669 & $0.007596^{* *}$ \\
\hline
\end{tabular}

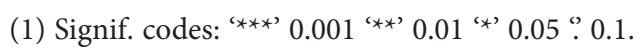

(2) Wald test $=232.3$ on $15 \mathrm{df}, \mathrm{p}=0$.

The results show that the variables variation in size-1 yr, return-1yr, and return-3yrs are not significant, so a new model is defined that only includes the statistically significant variables at a minimum significance level of $10 \%$ (Table 10).

The ANOVA contrast (Table 11) indicates that the model with eleven variables is more explicative. The Wald test shows that the coefficients of the model are significantly different from zero.

Table 10. Parameters of the Andersen-Gill model (8 variables) - Bond funds

\begin{tabular}{|l|c|c|c|c|c|}
\hline \multicolumn{1}{|c|}{ Variable } & coef & $\exp ($ coef $)$ & se(coef) & $\mathrm{z}$ & $\operatorname{Pr}(>|\mathrm{z}|)$ \\
\hline Age & -0.041 & 0.960 & 0.009 & -4.698 & $2.62 \cdot 10^{-6 * * *}$ \\
\hline Fund family =2 & -0.248 & 0.781 & 0.138 & -1.798 & $0.07224 \cdot$ \\
\hline Fund family = 3 & -0.876 & 0.416 & 0.300 & -2.920 & $0.003498^{* *}$ \\
\hline Size & -0.175 & 0.839 & 0.042 & -4.206 & $2.60 \cdot 10^{-5 * * *}$ \\
\hline Variation in size_2 yrs & -0.008 & 0.992 & 0.002 & -4.664 & $3.10 \cdot 10^{-6 * * *}$ \\
\hline Deviation_1 yr & 0.266 & 1.305 & 0.046 & 5.745 & $9.20 \cdot 10^{-9}$ *** \\
\hline Deviation_3 yrs & -0.232 & 0.793 & 0.055 & -4.230 & $2.33 \cdot 10^{-5 * * *}$ \\
\hline Sharpe ratio & -0.015 & 0.985 & 0.007 & -2.193 & $0.028325^{*}$ \\
\hline Rating = 2 & -0.434 & 0.648 & 0.173 & -2.504 & $0.012291^{\star}$ \\
\hline Rating = 3 & -0.468 & 0.626 & 0.177 & -2.642 & $0.008238^{* *}$ \\
\hline Rating = 4 & -0.681 & 0.506 & 0.211 & -3.221 & $0.001276^{* *}$ \\
\hline Rating = 5 & -1.402 & 0.246 & 0.391 & -3.586 & $0.000336^{* * *}$ \\
\hline
\end{tabular}

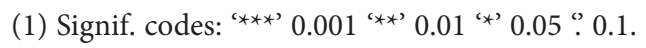

(2) Wald test $=216.6$ on $12 \mathrm{df}, \mathrm{p}=0$.

Table 11. ANOVA contrast between the models in Table 9 and Table 10

\begin{tabular}{|c|c|c|c|c|}
\hline & Loglik & Chisq & Df & $\mathrm{P}(>\mid$ Chi $\mid)$ \\
\hline 1 & -1984.9 & & & \\
\hline 2 & -1980.2 & 9.5142 & 3 & $0.02318^{\star}$ \\
\hline
\end{tabular}

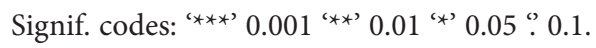


All coefficients $\beta$ of the significant variables (Table 9) are negative except for the coefficient of the variable deviation_1year. A negative sign implies that the higher the value of the variables, the lower the risk of the mutual fund disappearing. On the other hand, a positive sign means that an increase in the variable implies an increase in the risk of disappearance.

The value of the hazard ratio for each significant variable leads us to affirm the following statements. For each year the fund remains alive the risk of disappearing decreases by $4 \%$, confirming that younger bond funds (H1) are more likely to disappear. Furthermore, for each percentage point that size, variation in size_2yr, and deviation_3yrs increases, the mortality risk decreases by approximately $0.091 \%{ }^{5}, 0.636 \%$, and $17.5 \%$, respectively. These results confirm the hypothesis that larger bond funds $(H 2, H 3)$ are less likely to disappear. Likewise, greater return decreases the risk of a fund disappearing (H4). On the other hand, $H 5$ is not confirmed because higher 3 -years volatility decreases the risk but higher 1-year volatility increases it. This last result is contrary to that presented in the literature review.

Regarding the effect of the Sharpe ratio on survival capacity, the H6 is confirmed since a higher Sharpe ratio translated into a lower probability of disappearance.

The Morningstar rating of the bond funds behaves differently depending on the fund category, evaluated by their number of stars. The estimate of the hazard ratio at the low and medium levels ( 2 and 3 stars) is not significant, whereas this value in funds with higher ratings ( 4 and 5 stars) is less than 1 with respect to the reference group. Therefore, funds rated as 4 or 5 stars are less likely to disappear than those with a low rating (1 star) in the Spanish market.

Last, regarding the final hypothesis about the effect of the fund family, it can be observed that the estimate of the hazard ratio for both groups (independent and insurance companies) is less than 1 with respect to the reference group (banks). When the fund family is independent or an insurance company, they are at less risk of disappearing than funds managed by banks, confirming the hypothesis proposed in the literature section.

b) Equity funds

In this case, the results obtained using the Cox regression show that the model does not meet the proportional hazard assumption, so the Andersen-Gill model is applied. Table 12 shows the parameters of the Andersen-Gill model for the equity funds group.

The results show that the variables variation in size_1 year, return_1 year, deviation_1 year, and deviation_3 years are not significant in the disappearance of these types of funds. Therefore, a new model is defined that includes only the statistically significant variables at a minimum significance level of $10 \%$ (Table 13), and the two models are contrasted (Table 14).

The ANOVA contrast indicates that the model with 7 variables is more explicative. The Wald test shows that the coefficients of the model are significantly different from zero.

\footnotetext{
5 The effect of the variable size does not have a direct reading in the model as it is measured with the total net assets logarithm. The percentage variation of the risk of disappearing is obtained using the following expression: $(1-\exp ($ coef $) \times 0.01) / \mathrm{e}-1$.
} 
Table 12. Parameters of the Andersen-Gill model (11 variables) - Equity funds

\begin{tabular}{|l|c|c|c|c|c|}
\hline \multicolumn{1}{|c|}{ Variable } & coef & exp(coef) & se(coef) & $\mathrm{z}$ & $\operatorname{Pr}(>|\mathrm{z}|)$ \\
\hline Age & -0.037 & 0.964 & 0.013 & -2.787 & $0.005327^{* *}$ \\
\hline Fund family = 2 & -0.767 & 0.464 & 0.192 & -4.002 & $6.29 \cdot 10^{-5 * * *}$ \\
\hline Fund family = 3 & -0.483 & 0.617 & 0.293 & -1.647 & 0.099587. \\
\hline Size & -0.441 & 0.643 & 0.065 & -6.753 & $1.45 \cdot 10^{-11 * * *}$ \\
\hline Variation in size_1 yr & 0.005 & 1.005 & 0.004 & 1.319 & 0.187055 \\
\hline Variation in size_2 yrs & -0.011 & 0.989 & 0.003 & -3.743 & $0.000182^{* * *}$ \\
\hline Return_1 yr & 0.015 & 1.016 & 0.015 & 1.055 & 0.291309 \\
\hline Return_3 yrs & -0.049 & 0.952 & 0.015 & -3.350 & $0.000807^{* * *}$ \\
\hline Deviation_1 yr & -0.034 & 0.967 & 0.022 & -1.515 & 0.129693 \\
\hline Deviation_3 yrs & 0.032 & 1.033 & 0.023 & 1.382 & 0.167043 \\
\hline Sharpe ratio & -0.502 & 0.605 & 0.192 & -2.620 & $0.0088011^{* *}$ \\
\hline Rating = 2 & 0.275 & 1.316 & 0.205 & 1.339 & 0.180729 \\
\hline Rating = 3 & 0.396 & 1.486 & 0.195 & 2.032 & $0.042196^{*}$ \\
\hline Rating = 4 & 0.395 & 1.485 & 0.224 & 1.765 & 0.077606. \\
\hline Rating = 5 & 1.318 & 3.736 & 0.444 & 2.970 & $0.002975^{* *}$ \\
\hline
\end{tabular}

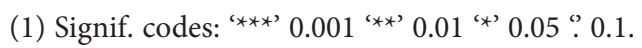

(2) Wald test $=337.9$ on 15 df. $p=0$.

The coefficients $\beta$ of age, size, variation in size_2 years, return_3 years, and Sharpe ratio (Table 13) are negative, so the higher the value of these variables, the less the risk of the mutual fund disappearing. Moreover, the value of the hazard ratio for each significant variable leads us to affirm the following statements. For each additional year the fund remains alive, the risk of it disappearing decreases by 3.6\%. And, for each percentage point that size, variation in size_2 years, and return_3 years increases, the mortality risk decreases by approximately $0.215 \%{ }^{6}, 0.1 \%$, and $4.5 \%$, respectively. Therefore, these results confirm that younger $(H 1)$ and smaller $(H 2)$ equity funds are more likely to disappear. Capital outflows $(H 3)$ and poor past performance $(H 4)$ also increase the likelihood of disappearance for this type of funds.

Table 13. Parameters of the Andersen-Gill model (7 variables) - Equity funds

\begin{tabular}{|c|c|c|c|c|c|}
\hline Variable & coef & $\exp ($ coef $)$ & se(coef) & $\mathrm{z}$ & $\operatorname{Pr}(>|z|)$ \\
\hline Age & .0 .036 & 0.965 & 0.013 & -2.822 & $0.004766^{* *}$ \\
\hline Fund family $=2$ & -0.711 & 0.491 & 0.184 & -3.860 & $0.000113^{* * *}$ \\
\hline Fund family $=3$ & -0.502 & 0.606 & 0.292 & -1.721 & 0.085304 . \\
\hline Size & -0.462 & 0.630 & 0.063 & -7.376 & $1.63 \cdot 10^{-13 * * *}$ \\
\hline Variation in size_2 yrs & -0.009 & 0.991 & 0.002 & -3.943 & $8.05 \cdot 10^{-5 * * *}$ \\
\hline Return_3 yrs & -0.046 & 0.955 & 0.013 & -3.412 & $0.000645^{\star * *}$ \\
\hline
\end{tabular}

$\overline{{ }^{6} \text { Value obtained from }}$ the following expression $(1-\exp ($ coef $) \times 0.01) / e-1$ 
End of Table 13

\begin{tabular}{|l|c|c|c|c|c|}
\hline \multicolumn{1}{|c|}{ Variable } & coef & $\exp ($ coef $)$ & se(coef) & $\mathrm{z}$ & $\operatorname{Pr}(>|z|)$ \\
\hline Sharpe ratio & -0.274 & 0.761 & 0.082 & -3.328 & $0.000875^{* * *}$ \\
\hline Rating = 2 & 0.264 & 1.303 & 0.201 & 1.314 & 0.188884 \\
\hline Rating = 3 & 0.394 & 1.483 & 0.194 & 2.030 & $0.042404^{*}$ \\
\hline Rating = 4 & 0.331 & 1.392 & 0.223 & 1.487 & 0.136929 \\
\hline Rating = 5 & 0.182 & 3.261 & 0.431 & 2.744 & $0.006073^{* *}$ \\
\hline
\end{tabular}

(1) Signif. codes: '***) 0.001 (**) 0.01 (*) 0.05 ? 0.1 .

(2) Wald test $=335.3$ on 11 df. $p=0$.

Table 14. ANOVA contrast between the models in Table 12 and Table 13

\begin{tabular}{|c|c|c|c|c|}
\hline & Loglik & Chisq & Df & $\mathrm{P}(>\mid$ Chi $\mid)$ \\
\hline 1 & -1284.6 & & & \\
\hline 2 & -1281.4 & 6.301 & 4 & 0.1778 \\
\hline
\end{tabular}

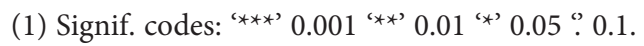

On the other hand, the results do not confirm that a greater volatility increases the risk of a fund disappearing (H5) because volatility in the short and long terms is not significant in the equity funds group.

The sixth hypothesis about the effect of the Sharpe ratio on survival capacity is confirmed since it can be observed that a higher Sharpe ratio decreases the probability of disappearance in the equity funds group.

Regarding the Morningstar Rating, the initial hypothesis (H7) is not confirmed because the results show that the funds ranked with 4 and 5 stars have a higher probability of disappearing.

Last, regarding the fund family, the estimate of the hazard ratio in both groups (independent and insurance companies) is less than 1 in relation to the reference group (banks). Thus, it can be confirmed that when the fund family is independent or is an insurance company the funds are at less risk of disappearing than when they are managed by banks ( $H 8)$.

\section{Discussion}

Table 15 is a summary of the effect that each variable has on the survival: (-) indicates a higher value of the variable decreases the risk of disappearing; (+) implies the opposite relationship; and $\left(^{*}\right)$ indicates that the variable is not significant.

Regarding age and size, younger funds with smaller assets are shown to be at greater risk of disappearing. These two hypotheses are confirmed for the two groups analyzed and reinforce the findings of different studies such as Zhao (2005), Bu and Lacey (2008), Rohleder et al. (2011), and Boubakri et al. (2014), among others. In both groups, for each year the fund is still alive the risk of it disappearing decreases by approximately $4 \%$. Additionally, the higher the total net assets, the lower the risk of mortality, decreasing by $0.091 \%$ for bond funds and $0.215 \%$ for equity funds. 
Table 15. Summary of the effect of each variable on the survival of mutual funds

\begin{tabular}{|c|c|c|}
\hline Variable & Bond funds & Equity funds \\
\hline Age & - & - \\
\hline Fund Family = 2 & - & - \\
\hline Fund Family $=3$ & - & - \\
\hline Size & - & - \\
\hline Variation in size_1 yr & * & * \\
\hline Variation in size_2 yrs & - & - \\
\hline Return_1 yr & * & * \\
\hline Return_3 yrs & * & - \\
\hline Deviation_1 yr & + & * \\
\hline Deviation_3 yrs & - & * \\
\hline Sharpe ratio & - & - \\
\hline Rating = 2 & * & * \\
\hline Rating $=3$ & * & + \\
\hline Rating $=4$ & - & * \\
\hline Rating $=5$ & - & + \\
\hline
\end{tabular}

Regarding variation in size, there is a relationship between mortality and capital outflow in the two years prior to the fund disappearing, as suggested by authors such as Ding (2006), Allen and Parwada (2006), Boubakri et al. (2014), and Andreu and Sarto (2016). Therefore, the third hypothesis is confirmed in both groups. Variation in size at one year, however, is not a significant variable for either of the groups analyzed.

Hypothesis 4, the effect of return on the survival of mutual funds, is verified for the two study groups; however, the Andersen-Gill model confirms that in the long term only the equity funds group is affected. In the short term, it is not a significant variable. The investor's timeframe for bond funds is long-term and they are willing to generate fewer returns to preserve capital, which explains why return is not significant in the model.

Volatility has also been incorporated for both the long and the short terms. While it is shown to not be a significant variable for the set of equity funds, it is a significant variable for bond funds. This result is explained by the risk profile of the investor in each group. Bond fund investors traditionally have low-risk profiles, whereas equity fund investors have higher risk profiles and their return prospects are also higher, so they are willing to assume greater risk. This explains why in the second group the variable volatility does not influence their survival. This result is consistent with Asebedo and Grable (2003). Regarding the set of bond funds, short-term volatility increases the risk of the fund disappearing, confirming the expected relationship. Greater volatility in the long term, however, decreases this risk. This result, contrary to most previous studies, can be explained by the situation of bond funds (and particularly of the public debt) in the Spanish market, which is characterized by higher volatility due to the risk premium reaching record highs in the period 2010-13. Within this context, bond funds, with very volatile assets in their portfolio but a very attractive return, remain in the market and even increase their net flow. 
The Sharpe ratio hypothesis is confirmed in the two groups analyzed and a higher Sharpe ratio translates into a lower probability of disappearance in the Spanish fund market. This result confirms the results of Lapatto and Puttonen (2018).

The seventh hypothesis about the effect of the Morningstar rating depends on the group analyzed. For the equity funds group, a higher rating negatively affects the survival capacity, while for the bond funds group 4- and 5-star rated funds are less likely to disappear than those with a low rating, confirming the hypothesis proposed in the literature review section.

Last, regarding the fund family, the Kaplan-Meier estimator enabled us to detect the possible influence of this variable on the survival of mutual funds. The Andersen-Gill model confirmed the importance of this variable and detected the sign of its influence, concluding that in both groups studied funds managed by banks are at greater risk of disappearing than when the fund family is independent or an insurance company. This result is opposite to that reported by Khorana et al. (2007). Closing and merging mutual funds for banks is easier because they have a wider range of funds with similar investment objectives, making it easier for them to redirect their clients' investments without any repercussions on the entity's reputation and prestige. This result is closely related to Park (2013), which concludes that funds belonging to the same family have a higher probability of disappearing since their closure reduces costs for the fund family.

\section{Conclusions}

In this study an analysis was carried out of fund survival in the Spanish market according to their investment objectives: bond and equity funds. The paper tested eight hypotheses related to age, size, variation in size, return, volatility, Sharpe ratio, Morningstar rating, and type of fund family, using the Andersen-Gill model. The results indicate that the impact of some variables is different depending on their category.

The significant variables in both groups are age, size, and Sharpe ratio. Younger and smaller funds have a higher probability of disappearing and funds with lower Sharpe ratios are likewise at greater risk. It should be pointed out that the effect intensity of the variables is the same for both groups.

The variables that affect the survival funds in different ways depending on the analysis group are return and volatility. The profile of the investor in bond funds is adverse to risk, which justifies the fact that return is not significant in this group since preserving capital takes precedence over gaining profitability. On the other hand, volatility is not a significant variable in the equity funds group, whereas it is in the bond fund group. This situation is also explained by the risk profile of the investor for each investment objective. An investor in equities is willing to assume more risk, so consequently volatility is less important to them.

The Kaplan-Meier and the Andersen-Gill models demonstrated that the funds managed by banks have a higher probability of disappearing than funds managed by independent groups or insurance companies.

Last, regarding the Morningstar Rating, the bond funds rated highly (4 or 5 stars) are more likely to survive in the Spanish market, whereas the equity funds rated highly are more likely to disappear. 
The main limitation of this study is the period analyzed because it includes the economic crisis period and the results may be different for a stable economic period. Therefore, the main future research lines could be a comparative analysis between different periods.

\section{Author contributions}

This article is a joint work of the three authors. M.G.B.M, L.F.A, and A.T. contributed to the research ideas, literature review and analysis and to writing the paper. All authors read and approved the final manuscript.

\section{Disclosure statement}

The authors declare no conflict of interest.

\section{References}

Allen, D., \& Parwada, J. (2006). Investor's response to mutual fund Company mergers. International Journal of Managerial Finance, 2(2), 121-135. https://doi.org/10.1108/17439130610657340

Andersen, P. K., \& Gill, R. D. (1982). Cox's regression model for counting processes: A large sample study. The Annals of Statistics, 10(4), 1100-1120. https://doi.org/10.1214/aos/1176345976

Andreu, L., \& Sarto, J. L. (2016). Financial consequences of mutual fund mergers. The European Journal of Finance, 22(7), 529-550. https://doi.org/10.1080/1351847X.2013.858055

Asebedo, G., \& Grable, J. (2004). Predicting mutual fund over-performance over a nine-year period. Journal of Financial Counseling and Planning, 15(1), 1-11.

Blake, C. R., \& Morey, M. R. (2000). Morningstar ratings and mutual fund performance. The Journal of Financial and Quantitative Analysis, 35(3), 451-483. https://doi.org/10.2307/2676213

Boubakri, N., Karoui, A., \& Kooli, M. (2014). Performance and survival of mutual funds mergers: Evidence from frequent and infrequent acquirers (Working Paper). https://doi.org/10.2139/ssrn.2375885

Brown, S., \& Goetzmann, W. (1995). Perfomance persistence. The Journal of Finance, 50(2), 679-698. https://doi.org/10.1111/j.1540-6261.1995.tb04800.x

Bu, Q., \& Lacey, N. (2008). On understanding mutual fund terminations. Journal of Economics and Finance, 33(1), 80-99. https://doi.org/10.1007/s12197-007-9022-2

Cameron, C., \& Hall, A. D. (2003). A survival analysis of Australian equity mutual funds. Australian Journal of Management, 28(2), 209-226. https://doi.org/10.1177/031289620302800201

Carhart, M. M. (1997). On persistence in mutual fund performance. The Journal of Finance, 52(1), 57-82. https://doi.org/10.1111/j.1540-6261.1997.tb03808.x

Cogneau, P., \& Hübner, G. (2015). The prediction of fund failure through performance diagnostics. Journal of Banking \& Finance, 50, 224-241. https://doi.org/10.1016/j.jbankfin.2014.10.004

Cox, D. R. (1972). Regression models and life-tables. Journal of the Royal Statistical Society, Series B, 34(2), 187-220. https://doi.org/10.1111/j.2517-6161.1972.tb00899.x

Del Guercio, D., \& Tkac, P. A. (2010). Star power: The effect of morningstar ratings on mutual fund flow. Journal of Financial and Quantitative Analysis, 43(4), 907-936. https://doi.org/10.1017/S0022109000014393

Ding, B. (2006). Mutual fund mergers: A Long-Term analysis (Working paper). https://doi.org/10.2139/ssrn.912927 
Elton, E. J., \& Gruber, M. J. (1996). Survivorship bias and mutual fund performance. The Review of Financial Studies, 9(4), 1097-1120. https://doi.org/10.1093/rfs/9.4.1097

Fabregat-Aibar, L., Terceño, A., \& Barberà-Mariné, M. G. (2017). Analysis of the survival capacity of mutual funds: A systematic review of the literature. International Journal of Managerial Finance, 13(4), 440-474. https://doi.org/10.1108/IJMF-10-2016-0185

Filip, D. (2014). Survivorship bias and performance of mutual funds in Hungary. Periodica Polytechnica Social and Management Sciences, 22(1), 47-56. https://doi.org/10.3311/PPso.7052

Fuentelsaz, L., Gómez, J., \& Polo, Y. (2004). Aplicaciones del análisis de supervivencia a la investigación en economía de la empresa. Cuadernos de Economía y Dirección de la Empresa, 19, 81-114.

Jayaraman, N., Khorana, A., \& Nelling, E. (2002). An analysis of the determinants and shareholder wealth effects of mutual fund mergers. Journal of Finance, 57(3), 1521-1551. https://doi.org/10.1111/1540-6261.00468

Kaplan, E., \& Meier, P. (1958). Nonparametric estimator for incomplete observations. Journal of the American Statistical Association, 53(282), 457-481. https://doi.org/10.1080/01621459.1958.10501452

Khorana, A., Tufano, P., \& Wedge, L. (2007). Board structure, mergers, and shareholder wealth: A study of the mutual fund industry. Journal of Financial Economics, 85(2), 571-598. https://doi.org/10.1016/j.jfineco.2006.05.002

Klein, J., \& Moeschberger, M. (2003). Survival analysis. Techniques for censored and truncated data. Springer.

Kleinbaum, D., \& Klein, M. (2012). Survival analysis. A self-learning text. Springer. https://doi.org/10.1007/978-1-4419-6646-9

Lapatto, A., \& Puttonen, V. (2018). Life after death: acquired fund performance. Managerial Finance, 44(3), 389-402. https://doi.org/10.1108/MF-02-2017-0031

Linnainmaa, J. T. (2013). Reverse survivorship bias. The Journal of Finance, 68(3), 789-813. https://doi.org/10.1111/jofi.12030

Lunde, A., Timmermann, A., \& Blake, D. (1999). The hazards of mutual fund underperformance: A Cox regression analysis. Journal of Empirical Finance, 6(2), 121-152. https://doi.org/10.1016/S0927-5398(98)00013-9

Massa, M., \& Patgiri, R. (2009). Incentives and mutual fund performance: Higher performance or just higher risk taking? The Review of Financial Studies, 22(5), 1777-1815. https://doi.org/10.1093/rfs/hhn023

McLemore, P. (2019). Do mutual funds have decreasing returns to scale? Evidence from fund mergers. Journal of Financial and Quantitative Analysis, 54(4), 1683-1711. https://doi.org/10.1017/S0022109018001023

Namvar, E., \& Phillips, B. (2013). Commonalities in investment strategy and the determinants of performance in mutual fund mergers. Journal of Banking and Finance, 37(2), 625-635. https://doi.org/10.1016/j.jbankfin.2012.10.001

Oehler, A., Höfer, A., Horn, M., \& Wendt, S. (2018). Do mutual fund rating provide valuable information for retail investors? Studies in Economics and Finance, 35(1), 137-152. https://doi.org/10.1108/SEF-05-2017-0120

Park, M. (2013). Understanding merger incentives and outcomes in the US mutual fund industry. Journal of Banking \& Finance, 37(11), 4368-4380. https://doi.org/10.1016/j.jbankfin.2013.07.048

Rohleder, M., Scholz, H., \& Wilkens, M. (2011). Survivorship bias and mutual fund performance: Relevance, significance, and methodical differences. Review of Finance, 15(2), 441-474. https://doi.org/10.1093/rof/rfq023

Schoenfeld, D. (1982). Partial residuals for the proportional hazards regression model. Biometrika, 69(1), 239-241. https://doi.org/10.1093/biomet/69.1.239 
Sherrill, D. E., \& Stark, J. R. (2018). ETF liquidation determinants. Journal of Empirical Finance, 48, 357-373. https://doi.org/10.1016/j.jempfin.2018.07.007

Ter Horst, J. R., Nijman, T. E., \& Verbeek, M. (2001). Eliminating look-ahead bias in evaluating persistence in mutual fund performance. Journal of Empirical Finance, 8(4), 345-373. https://doi.org/10.1016/S0927-5398(01)00032-9

Terceño, A., Barberà-Mariné, G. M., Fabregat-Aibar, L., \& Sorrosal-Forradellas, M. T. (2018). The behaviour of non-surviving Spanish funds according to their investment objectives. In C. Berger-Vachon, A. Gil Lafuente, J. Kacprzyk, Y. Kondratenko, J. Merigó, \& C. Morabito (Eds.), Complex systems: Solutions and challenges in economics, management and engineering. Studies in systems, decision and control (Vol. 125, pp. 439-450). Springer, Cham. https://doi.org/10.1007/978-3-319-69989-9_26

Zhao, X. (2005). Exit decisions in the U.S. mutual fund industry. The Journal of Business, 78(4), 13651402. https://doi.org/10.1086/430863 